reported by Mr. Fowler, and there is thus no strong evidence that the Pennine mineralization was not completed before the Permian rocks were deposited. The Great Sulphur Vein was later than much of the mineralization, but Dunham's main conclusions (Quart. Journ. Geol. Soc., xc, 689) are not seriously affected by the new observations.

I should like to correct the misleading "Lower Permian" applied to the Marl Slate and Magnesian Limestone; the rocks are certainly of Upper Permian age, equivalent to the German Kupferschiefer and Zechstein (cf. Westoll, 1941, Geol. Mag., lxxviii, 37).

Marischal College, Aberdeen.

T. S. WESTOLL. 24th May, 1943.

\title{
THE CLEVELAND AXIS
}

SIR,-May I crave space for three comments :-

(1) Now that Dr. Rastall has established the existence of YeovilianAalenian pebble beds exactly on the central line of the axis, he will have proved his case for movement of the axis if he can establish their absence on either side.

(2) If he has established that Callovian, Oxfordian, or Corallian Beds are involved in the anticline, all that he said about these formations in his article is still irrelevant, because it applied to their development throughout the Yorkshire basin.

(3) Since I do not admit that any facts yet published are inconsistent with my generalization (and (1) above, could not have been "brushed aside" ten years before it was published) my generalization was not sweeping according to Dr. Rastall's definition.

Hurstcote, Cumnor, OXFORD.

W: J. Arkell. 21st May, 1943.

The pebble-beds of the Dogger were described by Young and Bird in 1822 and by John Phillips in 1829. Later writers, especially Hudleston and the Geological Survey, confused the subject by persistently calling them concretions and nodules. Their true nature was pointed out by Kendall in 1902 and by myself in 1905.

Dr. Arkell has written more than once of the Jurassic passing over the Cleveland anticline. Now the main point of Lamplugh's discussion was that in the Jurassic Cleveland was a geosyncline. The pre-Permian and Tertiary anticlinal uplifts had nothing to do with the character of Jurassic sedimentation.

Since the Kellaways facies of the Oxfordian still exists in considerable force in the (Tertiary) syncline of North Cleveland and the Corallian rocks come within three or four miles of the central axis my discussion of these strata was completely relevant to my purpose, which was to show that the depression of the geosyncline was not uninterrupted.

R. H. Rastall. 